\title{
The Effect of Work Autonomy and Workload on Job Satisfaction of Female Workers in the Banking Sector: Mediating the Role of Work Life Balance
}

\author{
Iqbal Ramadhani Fuadiputra ${ }^{1 *}$; Khusnul Rofida Novianti ${ }^{2}$ \\ ${ }^{1,2}$ Department of Management, Universitas Muhammadiyah Malang \\ Jl. Bendungan Sutami No. 188, Sumbersari, Malang, Jawa Timur 65145, Indonesia \\ 1iqbalramadhanif@umm.ac.id; ${ }^{2 k h u s n u l r o f i d a @ u m m . a c . i d ~}$
}

Received: $11^{\text {th }}$ August 2020/ Revised: $03^{\text {rd }}$ November 2020/ Accepted: $09^{\text {th }}$ November 2020

\begin{abstract}
How to Cite: Fuadiputra, I. R., \& Novianti, K. R (2020). The effect of work autonomy and workload on job satisfaction of female workers in the banking sector: Mediating the role of work life balance. The Winners, 21(2), 85-91.

https://doi.org/10.21512/tw.v21i2.6908
\end{abstract}

\begin{abstract}
The research focused on the role of work-life balance to mediate the effect of work autonomy and workload on female workers' job satisfaction, particularly in the banking sector. By applying quantitative approach and data collection, the research used questionnaire to 100 female workers in the banking sector in Malang city, East Java, and analyzed using Partial Least Square (PLS) software. The results show that workload has a significant effect on work-life balance. Work autonomy, workload, and work-life balance have a direct and insignificant effect on job satisfaction. Nevertheless, the research highlights the importance of managing work-life balance especially for female workers related to high workload and less autonomy for their job satisfaction in the banking sector especially in Malang.
\end{abstract}

Keywords: work autonomy, workload, job satisfaction, female workers, banking sector, work-life balance

\section{INTRODUCTION}

Work-life balance has been widely used as a precursor to work and life satisfaction since 25 years ago. Most researchers consider the influence of worklife balance (such as autonomy, work-life conflicts) on job satisfaction as a direct and indirect relationship. Mas-Machuca, Berbegal-Mirabent, and Alegre, (2016), as well as Hoobler, Wayne and Lemmon (2009) have done research on work-life balance by focusing on female workers with multiple roles. Female employment in Indonesia is reported to have increased by $17 \%$ in 2019 (ILOSTAT, 2020), while one of the largest sectors has been the banking sector. Indonesia has experienced a significant increase in female workers based on data from the Central Statistics Agency recorded until February 2019 that the workforce for women reaches $55 \%$ of the total 140 million people in the force. It is essential for employees to have good work-life balance, so they feel engaged and loyal for the long term to their organization.

Work-life balance is a compromise between two entirely separate roles played by a person, namely work and family roles, which add happiness to the life of the role-holder (Shaffer et al., 2016). Work-life balance is, thus, a time-sharing arrangement between work and family by an employee. Its imbalance in either type, when work spills into the family realm or when family problems spill over into the work domain, is a possible cause of stress and unconstructive working attitudes. Consequently, they might favorably lead to burnout (Tziner et al., 2015; Rubio et al., 2015). Although the work-life balance or imbalance will positively or adversely impact employee performance (Anwar, Hansu, \& Janjua, 2013), a work-life balance and imbalance analysis concerning employee performance as an outcome variable seem crucial (Konrad \& Mangel, 2000; Ahmad, 2008). The work-life mismatch may have significant consequences for organizations, such as low productivity and bad results (Cohen \& Liani, 2009).

The role of workers in maintaining a worklife balance is well known (Rorondo \& Kincaid, 2008). Individual workers or managers have various choices, for example, flexible-hour programs to pay for additional time, to decide the balance.

Female workers usually deals with having problems of being good housewives or good workers (Noor, 2004) since they need to protect their work life and privacy. The process of managing work-life balance is a major challenge for individuals and organizations 
(Zhang et al., 2017; Zhang, Griffeth \& Fried, 2012). Work autonomy has special importance toward worklife balance as it allows workers to perform effectively and efficiently. As one of job-related variables that can impact a person's well-being, work autonomy provides freedom and control for employees' performance. This freedom is related to decide the method, schedule, and other ways of doing work. Employees who have better control over their work are considered less stressed, so they tend to be happier at work. Freedom also means flexibility which provides a better balance to competing demand for work and personal life. Higher value of work autonomy expands the opportunity of achieving better work-life balance.

Byrne (2005) defines work-life balance as juggling at any given point in time five facets of one's life-job, family, friends, health and self. Clutterbuck (2003) state that it is the knowledge of various energy and time demands, and also the ability to assign time and energy among different job and life fields, and then options to submit and make. Work-life balance provides activities that will potentially improve employee efficiency and versatility in meeting different requirements. Issues of work-life balancestress levels, competition and workplace insecuritiesat workplace occurs to be extremely important since they might cause instability in work-life balance (Bonney, 2005).

Autonomy designs jobs in a way that gives employees a broad scope to enact the job (Patterson et al., 2005). Increased autonomy helps workers to be more flexible and innovative in doing their jobs. Researchers have shown that work autonomy has a positive effect on work-life balance, which the female workers need. (Bulger \& Fisher, 2012; and MasMachuca et al., 2016).

Job satisfaction is related to several aspects that need to be maintained and characterized as a pleasurable state of emotion (Al Jenaibi, 2010), which is a significant indicator of citizenship activity in organizations (Gyekye \& Haybatollahi, 2015). Organ and Konovsky (1989) point out that there are two constituents to work satisfaction: an effective aspect and a component that is not effective (cognitive). The effective aspect is employee emotional status, whereas the non-affective (cognitive) portion relates to the happiness associated with the work performance evaluation. Parnell and Crandall (2003), and Lovett, Coyle and Adams (2004) identify work satisfaction as the essential since it often becomes the main subject of research regarding industrial/organizational psychology as well as organizational and social behavior.

The banking sector is also indicated to have had a high turnover rate due to high workloads. Higher workload is recorded as the main driver that can reduce the quality of work-life balance. This also happens in Indonesia where the workload in the financial sector is merely high based on the results of interviews with workers burdened with loads of work targets by the company. Experts have shown that workload significantly affects work-life balance (Pandu, Balu \& Poorani, 2011) and Fan \& Smith, 2017). Thus, the proposed hypotheses are:

$\mathrm{H}_{1}$ : $\quad$ work autonomy has a positive effect on worklife balance

$\mathrm{H}_{2}$ : Workload has a positive effect on work-life balance

A number of researchers have indicated the relationship between several key drivers of quality of work-life-autonomy, workload, and work-life balance-on job satisfaction. The workers acquiring work-life balance tend to be satisfied in their jobs, which motivates them to commit high loyalty to the organization. Job satisfaction is a concept that is frequently used to present a strategic move for a successful organization. Positive and significant effects of job autonomy on job satisfaction are found by Gözükara \& Çolakoğlu (2016).

Workload and work-life balance are considered to have significant and positive effects on job satisfaction (Fan \& Smith, 2017; Mušura, Koričan \& Krajnović, 2013; Haar et al., 2014; Mas-Machuca et al., 2016; Talukder Vickers \& Khan, 2018).

On the other hand, Holland et al. (2019) come up with different results that work-life balance does not have a significant effect on job satisfaction. This inconsistent finding needs to be reviewed in the banking sector. Thus, the proposed hypotheses are:

$\mathrm{H}_{3}$ : Job autonomy has a positive effect on job satisfaction

$\mathrm{H}_{4}$ : work load has a positive effect on job satisfaction

$\mathrm{H}_{5}$ : work-life balance has a positive effect on job satisfaction

A good work-life balance will affect individual job satisfaction as well as other outcomes in an organization. Holland et al. (2019) point out that work-life balance has a mediating effect between work autonomy and workload on job satisfaction. The hypotheses are formulated to be:

$\mathrm{H}_{6}$ : work-life balance has a mediating effect of work autonomy on job satisfaction

$\mathrm{H}_{7}$ : work-life balance has a mediating effect on workload on job satisfaction

Briefly, the connection between the variables and the hypotheses is shown in Figure 1. The research aims to examine the effect of work autonomy and workload mediated by work-life balance on job satisfaction in the banking sector, especially for female workers who live in Malang due to accessibility and banking complexity. It is expected that the research gives an insight for managerial level about managing work-life balance and other organizational outcome in banking sector. 


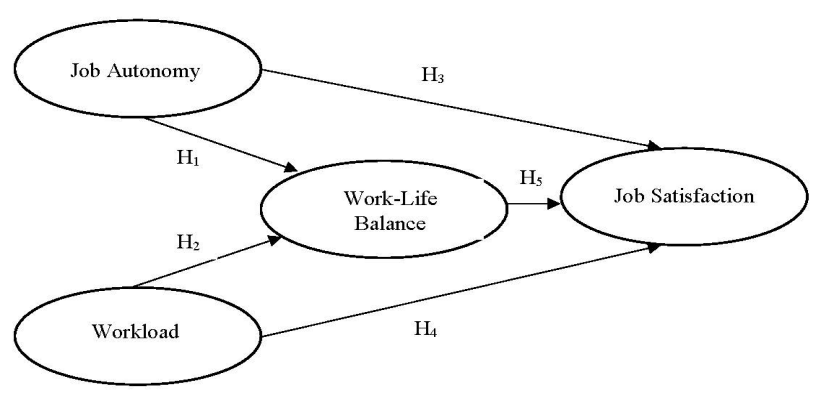

Figure 1 Research Framework

\section{METHODS}

A quantitative approach is applied to describe the relationship between the variables tested, namely work autonomy and workload on job satisfaction mediated by work life balance. The population are female workers in the banking sector in Malang, East Java. Using non-probability sampling from the number of unidentified populations, the minimum number of samples is based on the variables (Cooper \& Schindler, 2014). Hair et al. (1998) state that the minimum sample size with the variable $\leq 5$ must be 100 or more. Thus 100 respondents are involved as samples in the research.

Data measurement uses online questionnaires, which are divided into two parts: 1) respondent demographics; and 2) research variables-work autonomy, workload, work-life balance and job satisfaction. A five-point Likert scale is used, ranging from 1 (strongly disagree) to 5 (strongly agree). Work autonomy is measured using the QPS Nordic questionnaire (Elo et al., 2000) with 15 items. Workload is measured by five items adjusted to the Quantitative Workload Inventory (Spector \& Jex, 1998). Work-life balance is measured using a 15 -item Work Interference with Personal Life (WIPL) questionnaire by FisherMcAuley et al. (2003). Job satisfaction is measured by six items by Tsui et al. (1992). Data analysis uses Smart Partial Least Squares software (Smart-PLS) to describe the relationship between variables and indicator using path model, consisting of three stages, namely data analysis, external and internal model evaluation, and hypothesis testing. The Sobel test is used to examine the mediating effect of work-life balance on the relationship between work autonomy and workload on job satisfaction.

\section{RESULTS AND DISCUSSIONS}

As seen in Table 1, the following descriptions of respondents can be briefly elaborated that $38 \%$ are single and $62 \%$ are married, $24 \%$ are between 41 to 45 years old, and most of the length of work is between one and two years. $79 \%$ of the major respondents are graduated from university.
Table 1 Demographics of Respondents

\begin{tabular}{lccc}
\hline \multicolumn{1}{c}{ Detail } & Item & Frequency & $\mathbf{\%}$ \\
\hline Gender & Women & 100 & 100 \\
Age (years) & $20-25$ & 12 & 12,5 \\
& $26-30$ & 22 & 22,3 \\
& $31-35$ & 20 & 20 \\
& $36-40$ & 12 & 12,5 \\
Status & $41-45$ & 24 & 24,3 \\
Length of service & $>46$ & 10 & 8,4 \\
& Married & 38 & 38 \\
& Single & 62 & 62 \\
& $<1$ year & 9 & 9 \\
& $1-2$ years & 32 & 32 \\
& $3-4$ years & 24 & 24 \\
Education & 5-6 years & 20 & 20 \\
& $>6$ years & 15 & 15 \\
& High & 2 & 2 \\
& school & & \\
& Diploma & 6 & 6 \\
& Bachelor & 79 & 79 \\
& Magister & 13 & 13 \\
\hline
\end{tabular}

Source: own primary data (2020)

The results of the evaluation of the external model are carried out through convergent validity and uni-dimensionality in Table 2. The most ideal loading value is above 0,7 (Vinzi et al., 2010), but loading scores between 0,5 and 0,7 are still acceptable (Hair et al, 1998).

In the research, no variables are found to experience an outer loading below 0,5 so there is no convergent validity problem. Uni-dimensionality is tested using composite reliability, in which the value must be higher than 0,7 of each variable. There were no problems in uni-dimensionality since the score is above 0,9 .

Table 2 External Load and Composite Reliability

\begin{tabular}{lccc}
\hline \multicolumn{1}{c}{ Variable } & AVE & $\sqrt{ }$ AVE & $\begin{array}{c}\text { Composite } \\
\text { Reliability }\end{array}$ \\
\hline Job Autonomy & 0,904 & 0,951 & 0,979 \\
Workload & 0,980 & 0,989 & 0,993 \\
Work Life Balance & 0,687 & 0,829 & 0,939 \\
Job satisfaction & 0,827 & 0,909 & 0,935 \\
\hline
\end{tabular}

Source: own primary data (2020)

Discriminant validity is done by comparing the cross loading value with the outer loading score. The score of external loading must be higher than cross 
loading. Partial Least Square (PLS) analysis shows that the outer loading of each variable is greater than the cross loading value. Therefore, no discriminant validity issue is detected, as shown in Table 3.

Table 3 Summary of External Model Evaluation

\begin{tabular}{lcccc}
\hline \multicolumn{1}{c}{ Build } & JA & WL & WLB & JS \\
\hline Job Autonomy (JA) & 0,907 & & & \\
Workload (WL) & 0,156 & 0,920 & & \\
$\begin{array}{l}\text { Work Life Balance } \\
\text { (WLB) }\end{array}$ & 0,107 & 0,599 & 0,859 & \\
Job Satisfaction (JS) & 0,260 & 0,048 & 0,157 & 0,944 \\
\hline
\end{tabular}

Source: own primary data (2020)

Inner model evaluation is measured by the coefficient of determination score (R-squared). $\mathrm{R}^{2}$ values were categorized into three classes: weak $(0,25)$, moderate $(0,5)$, and substantial $(0,75)$ (Hair et al, 1998). The research result shows the value of $\mathrm{R}$-squared is considered weak, as seen in Table 4.

Table 4 Evaluation of Inner Model

\begin{tabular}{lc}
\hline \multicolumn{1}{c}{ Build } & R-squared \\
\hline Job Autonomy (JA) & \\
Workload (WL) & \\
Work Life Balance (WLB) & 0,359 \\
Job Satisfaction (JS) & 0,092 \\
\hline
\end{tabular}

Source: own primary data (2020)
Seven hypotheses are proposed in this research. Table 5 summarizes the hypothesis testing of the direct effect of each variable. Work autonomy has no significant effect on work life balance. Workload has a significant effect on work life balance $\left(\mathrm{H}_{2}\right)$. The other three hypotheses $\left(\mathrm{H}_{3}, \mathrm{H}_{4}\right.$, and $\left.\mathrm{H}_{5}\right)$ have no significant effect on job satisfaction.

Table 6 summarizes the indirect effects of work autonomy and workload on job satisfaction mediated by work life balance. $\mathrm{H}_{6}$ predicts the mediating effect of work-life balance on the relationship between job autonomy and job satisfaction. $\mathrm{H}_{7}$ predicts the mediating effect of work life balance on the relationship between workload and job satisfaction. Figure 2 shows the hypothesis testing framework, whereas Table 6 describes the results.

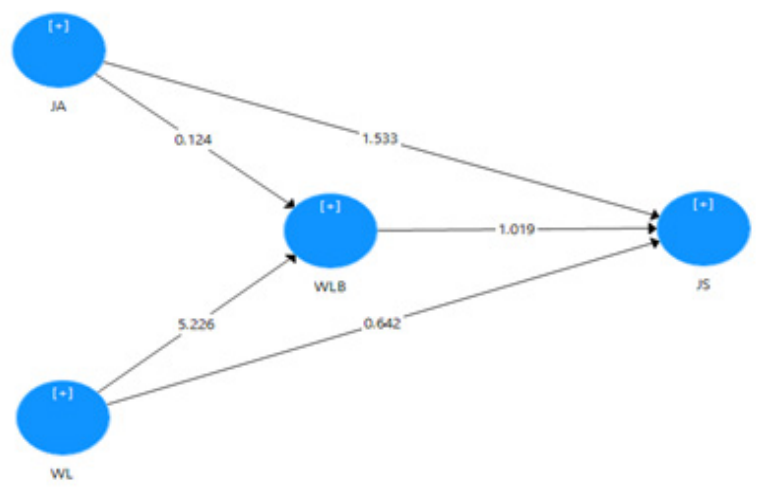

Figure 2 Hypothesis Results

Empirically, the results show that work autonomy has no significant effect on work-life balance. This result turns out to be different from

Table 5 Hypothesis Test for Direct Effect Research

\begin{tabular}{lcccc}
\hline \multicolumn{1}{c}{ Street } & T-statistic & $\begin{array}{c}\text { Original sample } \\
(\mathbf{O})\end{array}$ & P-value & Result \\
\hline $\mathrm{JA} \rightarrow \mathrm{WLB}$ & 0,131 & 0,014 & 0,896 & Not significant \\
$\mathrm{WL} \rightarrow \mathrm{WLB}$ & 5,575 & 0,569 & 0,000 & Urgent \\
$\mathrm{JA} \rightarrow \mathrm{JS}$ & 1,578 & 0,256 & 0,115 & Not significant \\
$\mathrm{WL} \rightarrow \mathrm{JS}$ & 0,634 & $-0,107$ & 0,536 & Not significant \\
$\mathrm{WLB} \rightarrow \mathrm{JS}$ & 1,051 & 0,195 & 0,294 & Not significant \\
\hline
\end{tabular}

Source: own primary data (2020)

Table 6 Hypothesis Test for Direct Effect Research

\begin{tabular}{ccccc}
\hline \multicolumn{1}{c}{ Street } & T-statistic & Original sample (O) & P-value & Result \\
\hline $\mathrm{JA} \rightarrow \mathrm{WLB} \rightarrow$ JS & 0,081 & 0,003 & 0,936 & Not significant \\
$\mathrm{WL} \rightarrow \mathrm{WLB} \rightarrow$ JS & 0,989 & 0,016 & 0,323 & Not significant \\
\hline
\end{tabular}

Source: own primary data (2020) 
previous research by Bulger and Fisher (2012) and Mas-Machuca et al. (2016). This occurs due to the low level of work autonomy obtained by women workers in the banking sector since they are majorly at the middle to lower level managerial level. Work and personal life must be implemented seamlessly, and should not be left to negative effects on one another. Both balance and imbalance are likely to impact overall performance teachers, as well as the corporation success (Guest, 2012). There are workers who believe in work-life policies of harmony such as versatility, family-friendly advantages, work-life services and projects. It demonstrates that employers are concerned in their benefits and health jobs. Therefore, the work satisfaction of is enhanced to encourage them in providing higher interaction rates and loyalty to its organizational goals and mission (Forsyth \& PolzerDebruyne, 2007), so they do not have adequate work autonomy. Moreover, in this position of banking sector, a worker is not given more authority because their position is administrative in nature, in which they tend to do almost same things every single day. Thus this position do not need more authority.

The results show that workload has a positive and significant effect on work-life balance. This direct effect strengthens the research by Chawla \& Shondi (2012) and Fan and Smith (2017). A higher workload will have an impact on decreasing the work-life balance of female workers in the banking sector. Based on observations, the workload will increase drastically when it is about time for the closing book period in the banking sector, usually at the end of the month, the mid-year report and the end of the year. Almost at these particular period, workers in the banking sector experience a decrease in their work-life balance.

The effect of work autonomy has no significant effect on job satisfaction, which turns out to be different from previous research by (Gözükara \& Çolakoğlu, 2016). The existence of work autonomy does not necessarily increase the level of job satisfaction of female workers in the banking sector. The level of job satisfaction is low since their positions do not necessarily require them to have authorities.

Furthermore, workload does not have a significant effect on job satisfaction, which shows contrast towards Fan and Smith (2017). The research finds that more workload leads to lower the job satisfaction level. Female workers prefers not to be burdened by piles of assignments which requires them to work overtime.

The work-life balance of female workers does not have a significant effect on job satisfaction. These results strengthen the research conducted by Holland et al. (2019), while differs from Mušura et al. (2013), Haar et al. (2014), Mas-Machuca et al. (2016), and Talukder et al. (2018). Due to the extremely high pressure at work, there is not a good balance between work and personal life of these female bank workers, which leads to lower job satisfaction level. In this case, female bank workers tend to see this as continuous routine, so their sense of satisfaction might not be fulfilled. Furthermore, the absence of work-life balance in banking sector is not only experienced by female workers in middle-lower managerial level but also in middle-top managerial level associated with the extensive workloads, especially at the end of month.

Additionally, the research finds that work autonomy and work satisfaction, mediated by worklife balance, have no indirect effect on job satisfaction for female workers in banking sector. These results support the research by Holland et al. (2019) that higher workload negatively impacts the well-being of individuals by reducing their satisfaction in maintaining a good and healthy work-life balance of women workers. In addition, the authority in banking employees itself has a large portion for workers in middle management and top management positions, in which they are considered to have more quality in carrying out tasks. These results indicate the importance of paying attention to improve aspects of work-life balance for female workers in banking sector. It It is considered that the workers are given more work autonomy and less extensive workloads, so the balance between work and private life can be realized, thus job satisfaction is fulfilled.

\section{CONCLUSIONS}

The research examines the relationship between work autonomy and workload on job satisfaction mediated by work-life balance, on female workers in banking sector. The affirmation and explanation of this case strengthens several preceding research on the importance of having a good work-life balance in relation to personal outcomes. The results indicate that all hypotheses are rejected except the relationship between workload and work-life balance. This is due to the fact that most of the respondents are in middlelow management positions, which makes their work authority are less likely to affect the work-life. This implies and gives an insight to the company leaders to pay attention to their female employees. It is, in addition, crucial for leaders to be aware that less workload and more job autonomy can significantly increase employees' job satisfaction.

The limitation of the research includes the number of samples that cannot be generalized, and all female bank workers in Malang. Future research can replicate this model using middle-higher level management level to validate and finding out the difference. This model can be used in other sectors such as industry, education, private, and government. It is suggested that further research uses several variables to add dependent variables such as quality of work life, work conflict, family work conflict, well-being, job performance and influential factors for leaving the organization. Likewise, moderating variable such as work incentives or other job-related variables can be added to expand the research scope. 


\section{REFERENCES}

Ahmad, A. (2008). Direct and indirect effects of workfamily conflict on job performance. The Journal of International Management Studies, 3(2), 176-180. http://www.jimsjournal.org/24\%20Aminah\%20 Ahmad.pdf.

Al Jenaibi, B. (2010). Job satisfaction: Comparisons among diverse public organizations in the UAE. Management Science and Engineering, 4(3), 60-79. http://dx.doi. org/10.3968/j.mse.1913035X20100403.007.

Anwar, J., Hansu, S. A. F., \& Janjua, S. Y. (2013). Worklife balance: What organizations should do to create balance? World Applied Sciences Journal, 24(10), 1348-1354. http://www.idosi.org/wasj/ wasj24(10)13/11.pdf.

Bonney, N. (2005). Overworked Britons? Parttime work and work-life balance. Work Employment Society, 19(2), 391-401. https://doi. org/10.1177/0950017005053182.

Bulger, C. A. \& Fisher, G. G. (2012). An ethical imperative for work/life balance. In N. P. Reilly, M. J. Sirgy and C. A. Gorman (Eds.), Work and Quality of Life: Ethica; Practices in Organizations (pp. 181-201). New York: Springer. https://doi.org/10.1007/97894-007-4059-4 10.

Byrne, U. (2005). Work-life balance: Why are we talking about it at all? Business Information Review, 22(1), 53-59. https://doi.org/10.1177/0266382105052268.

Chawla, D. \& Sondhi, N. (2012). Assessing the worklife balance among Indian female professionals. Indian Journal of Industrial Relations, 47(2), 341352. http://www.i-scholar.in/index.php/ijir/article/ view/41075.

Clutterbuck, D. (2003). Managing Work-Life Balance: A Guide for HR in Achieving Organisational and Individual Change. London: Chartered Institute of Personnel and Development.

Cooper, D. R. \& Schindler, P. S. (2014). Business Research Methods. New York: McGraw-Hill.

Cohen, A. \& Liani, E. (2009). Work-family conflict among female employees in Israeli hospitals. Personnel Review, 38(2),124-141. https://doi. org/10.1108/00483480910931307.

Elo, A.-L., Dallner, M., Gamberale, F., Hottinen, V., Knardahl, S., Lindström, K., Skogstad, A., \& Ørhede, E. (2000). Validation of the Nordic questionnaire for psychological and social factors at workQPSNordic. In M. Vartiainen, F. Avallone, and N. Anderson (Eds.), Innovative Theories, Tools, and Practices in Work and Organizational Psychology (pp. 47-57). Hogrefe \& Huber Publishers.

Gözükara, İ., \& Çolakoğlu, N. (2016). The effect of work family conflict mediation on the relationship between work autonomy and job satisfaction. Procedia Social and Behavioral Sciences, 229, 253-266. https://doi.org/10.1016/j.sbspro.2016.07.136.

Fan, J. \& Smith, A. P. (2017). The impact of workload and fatigue on performance. In L. Longo and M. C. Leva (Eds.), Human Mental Workload: Models and Applications. H-WORKLOAD 2017.
Communications in Computer and Information Science, 726 (pp. 90-105). Cham: Springer. http:// dx.doi.org/10.1007/978-3-319-61061-0_6.

Fisher-McAuley, G., Stanton, J., Jolton, J., \& Gavin, J. (2003). Modeling the relationship between work life balance and organizational results. In the Society's Annual Conference for Industrial-Organizational Psychology. Orlando, pp. 1-26.

Forsyth, S.\& Polzer-Debruyne,A. (2007). The organisational pay-offs for perceived work-life balance support. Asia Pacific Journal of Human Resources, 45(1), 113123. https://doi.org/10.1177/1038411107073610.

Guest, D. E. (2002). Perspectives on the study of work-life balance. Social Science Information, 41(2), 255-279. https://doi.org/10.1177/0539018402041002005.

Gyekye, S. A. \& Haybatollahi, M. (2015). Organizational citizenship behavior: An empirical investigation of the impact of age and job satisfaction on Ghanaian industrial workers. International Journal of Organizational Analysis, 23(2), 285-301. https://doi. org/10.1108/IJOA-08-2012-0586.

Haar, J. M., Russo, M., Suñe, A., \& Ollier-Malaterre, A. (2014). Work-life balance results on job satisfaction, life satisfaction and mental health: A study across seven cultures. Journal of Vocational Behavior, 85(3), 361-373. https://doi.org/10.1016/j.jvb.2014.08.010

Hair, J. F., Black, W. C., Babin, B. J., Anderson, R. E., \& Tatham, R. L. (1998). Multivariate Data Analysis ( $5^{\text {th }}$ Ed.). Upper Saddle River, NJ: Prentice Hall.

Hoobler, J. M., Wayne, S. J., \& Lemmon, G. (2009). Boss' perceptions of family-work conflict and women's promotability: Glass ceiling effect. Academy of Management Journal, 52(5), 939-957. https://doi. org/10.5465/amj.2009.44633700.

Holland, P., Tham, T. L., Sheehan, C., \& Cooper, B. (2019). The impact of perceived workload on nurses' satisfaction with work-life balance and intention to leave work. Applied Nursing Research, 49 (March), 70-76. https://doi.org/10.1016/j.apnr.2019.06.001.

International Labour Organization (ILOSTAT). (June $21^{\text {st }}$, 2020). Employment in industry, female (\% of female employment) (modeled ILO estimate). The World Bank. https://data.worldbank.org/indicator/SL.IND. EMPL.FE.ZS

Konrad, A. M. \& Mangel, R. (2000). The impact of work-life programs on firm productivity. Strategic Management Journal, 21(12), 1225-1237. https://doi. org/10.1002/1097-0266(200012)21:12<1225::AIDSMJ135>3.0.CO;2-3.

Lovett, S., Coyle, T., \& Adams, R. P. (2004), Job satisfaction and technology in Mexico. Journal of World Business, 39(3), 217-232. https://doi.org/10.1016/j. jwb.2004.04.002

Mas-Machuca, M., Berbegal-Mirabent, J., \& Alegre, I. (2016). Work-life balance and its relationship with organizational pride and job satisfaction. Journal of Managerial Psychology, 31(2), 586-602. https://doi. org/10.1108/JMP-09-2014-0272.

Mušura, A., Koričan, M., \& Krajnović, S. (2013). Work-life and life-work conflicting Croatian companies: Some perspectives. International Journal of Organization 
Theory \& Behavior, 16(1), 42-67. https://doi. org/10.1108/IJOTB-16-01-2013-B003.

Noor, N. M. (2004). Work-family conflict, the importance of work and family roles and the welfare of women. Journal of Social Psychology, 144(4), 389-405. https://doi.org/10.3200/SOCP.144.4.389-406.

Organ, D. W. \& Konovsky M. (1989), Cognitive versus affective determinants of organization citizenship behavior. Journal of Applied Psychology, 74(1), 157164. https://doi.org/10.1037/0021-9010.74.1.157.

Pandu, A., Balu, A., \& Poorani, K. (2011). Assessing worklife balance among Indian female professionals. The Indian Journal of Industrial Relations, 47(2), 341-352. http://www.publishingindia.com/ ijir/22/assessing-work-life-balance-among-itites-women-professionals/286/2098/https://doi. org/10.2307/23070581.

Parnell, J. A. \& Crandall, W. (2003), Propensity for participative decision-making, job satisfaction, organizational commitment, organizational citizenship behavior, and intention to leave among Egyptian managers. Multinational Business Review, 11(1), 45-65. https://doi. org/10.1108/1525383X200300003.

Patterson, M. G., West, M. A., Shackleton, V. J., Dawson, J. F., Lawthom, R., Maitlis, S., \& Wallace, A. M. (2005). Validating measures of organizational climate: in relation to managerial practices, productivity and innovation. Journal of Organizational Behavior, 26(4), 379-408. https://doi.org/10.1002/job.312.

Rorondo, D. M., \& Kincaid, J. F. (2008). Conflict, facilitation, and individual coping styles across the work and family domains. Journal of Managerial Psychology, 23(5), 484-506. https://doi. org/10.1108/02683940810884504.

Rubio, C., Osca, A., Recio, P., Urien, B., \& Peiró, J. M. (2015). Work-family conflict, self-efficacy, and emotional exhaustion: A test of longitudinal effects. Work and Organizational Psychology, 31(3), 147154. https://doi.org/10.1016/j.rpto.2015.06.004.
Shaffer, M. A., Reiche, B. S., Dimitrova, M. N., Lazarova, M., Chen, S., Westman, M., \& Wurtz, O. (2016). Work and family role adjustment of different types of global professionals: Scale development and validation. Journal of International Business studies, 47(2), 113-139. https://doi.org/10.1057/jibs.2015.26

Spector, P. E. \& Jex, S. M. (1998). Development of four self-report measures of job stressors and strain: Interpersonal conflict at work scale, organizational constraints scale, quantitative workload inventory, and physical symptoms inventory. Journal of Occupational Health Psychology, 3(4), 356-367. https://doi.org/10.1037/1076-8998.3.4.356.

Talukder, A. K. M., Vickers, M., \& Khan, A. (2018). Supervisor support and work-life balance: Impact on job performance in the Australian financial sector. Personnel Review, 43(7), 727-744. https://doi. org/10.1108/PR-12-2016-0314.

Tsui, A., Egan, T., \& O’Reilly, C. (1992). Being different: Relational demographics and organizational attachment. Administrative Sciences Quarterly, 37(4), 549-579. https://doi.org/10.2307/2393472.

Tziner, A., Rabenu, E., Radomski, R., \& Belkin, A. (2015). Work stress and turnoverintentions among hospital physicians: The mediating role of burnout and work satisfaction. Journal of Work and Organizational Psychology, 31(1), 207-213. https:// doi.org/10.1016/j.rpto.2015.05.001.

Vinzi, V. E., Chin, W. W., Henseler, J., \& Wang, H. (2010). Handbook of Partial Least Squares: Concepts, Methods and Applications. Berlin: Springer. https:// doi.org/10.1007/978-3-540-32827-8.

Zhang, M., Griffeth, R. W., \& Fried, D. D. (2012). Workfamily conflict and individual consequences. Journal of Managerial Psychology, 27(7), 696-713. https:// doi.org/10.1108/02683941211259520.

Zhang, W., Jex, S. M., Peng, Y., \& Wang, D. (2017). Exploring the effects of job autonomy on engagement and creativity: The role of moderation of performance stress and learning goal orientation. Journal of Business and Psychology, 32(3), 235-251. https://doi.org/10.1007/s10869-016-9453-X. 